\title{
RANCANG BANGUN SISTEM PEMBELAJARAN ONLINE BERBASIS MOODLE DI SEKOLAH TINGGI TEKNOLOGI INDONESIA
}

\author{
Mujiono ${ }^{1}$ \\ Program Studi Teknik Elektro Sekolah Tinggi Teknologi Indonesia \\ Email:k410ib@gmail.com \\ Syah Alam ${ }^{2}$ \\ Program Studi Teknik Elektro Universitas Trisakti \\ Email: syah.alam@trisakti.ac.id \\ Albert Gifson ${ }^{3}$ \\ Program Studi Teknik Elektro Institut Teknologi PLN \\ Email: albert.gifson@itpln.ac.id
}

\begin{abstract}
S : The Indonesian College of Technology (STTI) is a private university that has adequate infrastructure in the field of information technology. The face-to-face learning process in class that has been running so far still has weaknesses, plus the covid-19 pandemic makes lectures carried out online. The real problem faced by every STTI lecturer or student is mainly about the attendance of students or lecturers who are unable to attend. The STTI campus which organizes employee class lectures, where at some time you have to leave the city to work on a project, both maintenance and development. Likewise, at one point, a lecturer also has needs outside the city, for example, education and training, seminars and others that cannot be left behind. In this study, the design and construction of an e-learning learning system or digital "classroom" using MOODLE (Modular Object Oriented Dynamic Learning Environment) was carried out, which means a dynamic learning place using an object-oriented model. Moodle is a free Course Management System (CMS) application that can be accessed using a web browser and can be accessed without time and distance limits. The research activity begins by identifying the learning problem that you want to solve, collecting lecture data and analyzing data as a basis for the MOODLE configuration. The test results show that the STTI elearning system has run well and is in accordance with the design.
\end{abstract}

Keyword: Course Management System (CMS), e-learning, MOODLE, STTI

\begin{abstract}
ABSTRAK: Sekolah Tinggi Teknologi Indonesia (STTI) merupakan perguruan tinggi swasta yang mempunyai sarana dan prasarana di bidang teknologi informasi yang memadai. Proses pembelajaran tatap muka di kelas yang selama ini berjalan masih memiliki kelemahan, ditambah adanya pandemi covid-19 yang membuat perkuliahan dilaksanakan secara online. Masalah riil yang dihadapi oleh setiap dosen atau mahasiswa STTI terutama adalah tentang kehadiran mahasiswa atau dosen yang berhalangan hadir. Kampus STTI yang menyelenggarakan perkuliahan kelas karyawan, dimana dibeberapa waktu harus keluar kota untuk mengerjakan sebuah project baik maintenance ataupun develop. Demikian juga sebaliknya disuatu saat dosen juga memiliki kebutuhan diluar kota misal diklat, seminar dan lain-lain yang tidak bisa ditinggalkan. Pada penelitian ini dilakukan rancang bangun dan pembuatan sebuah sistem pembelajaran e-learning atau "ruang kelas" digital menggunakan MOODLE (Modular Object Oriented Dynamic Learning Environment) yang berarti tempat belajar dinamis dengan menggunakan model berorientasi objek. Moodle merupakan sebuah aplikasi gratis Course Management System (CMS) yang dapat diakses dengan menggunakan web browser dan dapat di akses tanpa batas jarak dan waktu. Kegiatan penelitian dimulai dengan melakukan identifikasi masalah pembelajaran yang ingin diselesaikan, melakukan pengumpulan data perkuliahan dan melakukan analisis data sebagai dasar dalam konfigurasi MOODLE. Hasil pengujian menunjukkan bahwa sistem e-learning STTI telah berjalan dengan baik dan sesuai dengan perancangan.
\end{abstract}

Kata Kunci: Course Management System (CMS), e-learning, MOODLE, STTI

\section{PENDAHULUAN}

$\mathrm{D}$ alam bidang pendidikan, pemanfaatan teknologi informasi dapat berupa pembelajaran online atau yang lebih dikenal dengan e-learning. Di dalam laman web-nya lldikti3.kemdikbud.go.id menyatakan e-learning is defined as "flexible learning experiences delivered through the use of information and computer technologies to be accessible anytime, anywhere, by anyone" (pengalaman belajar yang fleksibel yang memanfaatkan TIK dan dapat diakses kapan saja, di masa saja, oleh siapa saja).

Ada beberapa LMS (Learning Management System) yang cukup mumpuni, yaitu Google classroom, Edmodo dan MOODLE. Edmodo dirancang berbasis cloud merupakan aplikasi yang aman digunakan oleh pengajar dan siswa. Edmodo menggunakan desain yang mirip dengan Facebook. Demikian juga dengan Edmodo, Google classroom adalah layanan e-learning yang

\footnotetext{
${ }^{1}$ Program Studi Teknik Elektro Sekolah Tinggi Teknologi Indonesia

${ }^{2}$ Program Studi Teknik Elektro Universitas Trisakti

${ }^{3}$ Program Studi Teknik Elektro Institut Teknologi PLN
} 
disediakan google yang berbasis cloud. Pengguna harus mempunyai akun Google. Selain itu Google Classroom hanya bisa digunakan oleh lembaga yang mempunyai Google Apps for Education. (Hakim, 2016).

Berbeda dengan Edmodo dan Google classroom, MOODLE merupakan sebuah paket software, yang instalasinya membutuhkan hosting. MOODLE dapat diinstal di lingkup intranet yang bersifat lokal dan tanpa jaringan internet. Dalam MOODLE banyak pilihan modul dari pihak ketiga yang bisa digunakan, diantaranya untuk administrasi, kolaborasi, konten, antarmuka, komunikasi dan penugasan. Luaran dalam penelitian ini diharapkan adanya rancang bangun sistem pembelajaran e-learning untuk mahasiswa reguler maupun kelas karyawan dan adanya penerapan kuliah e-learning berbasis moodle di kampus STTI.

Selain beberapa hal diatas masalah riil yang dihadapi oleh setiap dosen atau mahasiswa STTI saat ini adalah tentang kehadiran mahasiswa atau dosen yang berhalangan hadir. Sebagian besar mahasiswa STTI terutama teknik Elektro Telekomunikasi adalah karyawan di sebuah perusahaan Telekomunikasi yang dimana dibeberapa waktu harus keluar kota untuk mengerjakan sebuah project baik maintenance ataupun develop. Demikian juga sebaliknya disuatu saat dosen juga memiliki kebutuhan diluar kota misal diklat dan lain-lain yang tidak bisa ditinggalkan. Disinilah dibutuhkan sebuah sistem yang bisa mengakomodir kebutuahan keduanya dalam proses perkuliahan.

Definisi e-learning adalah sebuah rangkaian proses pembelajaran yang menggunakan peralatan elektronik sebagai media pembawa informasi dalam menciptakan kemudahan proses belajar mengajar yang tidak terbatas pada tempat dan waktu. Moodle merupakan sebuah Course Management System (CMS) yang gratis. Moodle bisa digunakan dalam lingkup perguruan tinggi, sekolah, bisnis. Lebih dari 30.000 organisasi pendidikan di dunia saat ini menggunakan Moodle untuk pembelajaran online mereka dan untuk mengganti kelas tatap muka. Moodle bisa didownload semua orang di www.moodle.org secara gratis. Moodle diciptakan oleh Martin Dougiamas, seorang ahli computer dan pendidik di sebuah universitas di Perth, Australia. Moodle dikembangkan pertama kali pada Agustus 2002 dengan versi Moodle 1.0.

\section{METODOLOGI}

Metode dan tahapan penelitian ini menggunakan sifat penelitian eksperimental yang mengacu pada metode kuantitatif dengan rancang bangun sistem pembelajaran online. Subyek penelitian yaitu mahasiswa Teknik Elektro, sebagai sumber daya terdekat dan kemudahan dalam memperoleh data yang dibutuhkan. Penelitian dilakukan selama tiga bulan (Februari - April 2020) di Sekolah Tinggi Teknologi Indonesia Jl. Matraman no. 3-5 Jakarta Timur.

Dari uraian yang telah di sampaikan, maka diperlukan suatu sistem yang dapat memecahkan masalah yang ada. Sistem baru yang diperlukan diharapkan dapat mengatasi beberapa hal sebagai berikut :

1. Sistem dapat memfasilitasi dosen dan mahasiswa untuk melakukan proses belajar mengajar tanpa harus melalui proses tatap muka secara langsung. Dengan kata lain perkuliahan dapat berlangsung tanpa kehadiran mahasiswa secara langsung.

2. Sistem dapat mempermudah akses mahasiswa untuk memperoleh materi yang diajarkan.

3. Memberikan akses kemudahan bagi mahasiswa untuk berkonsultasi kepada dosen seputar materi perkuliahan.

Analisis sistem pembelajaran dengan sistem e-learning dapat dilihat pada Gambar Flowchart berikut ini : 


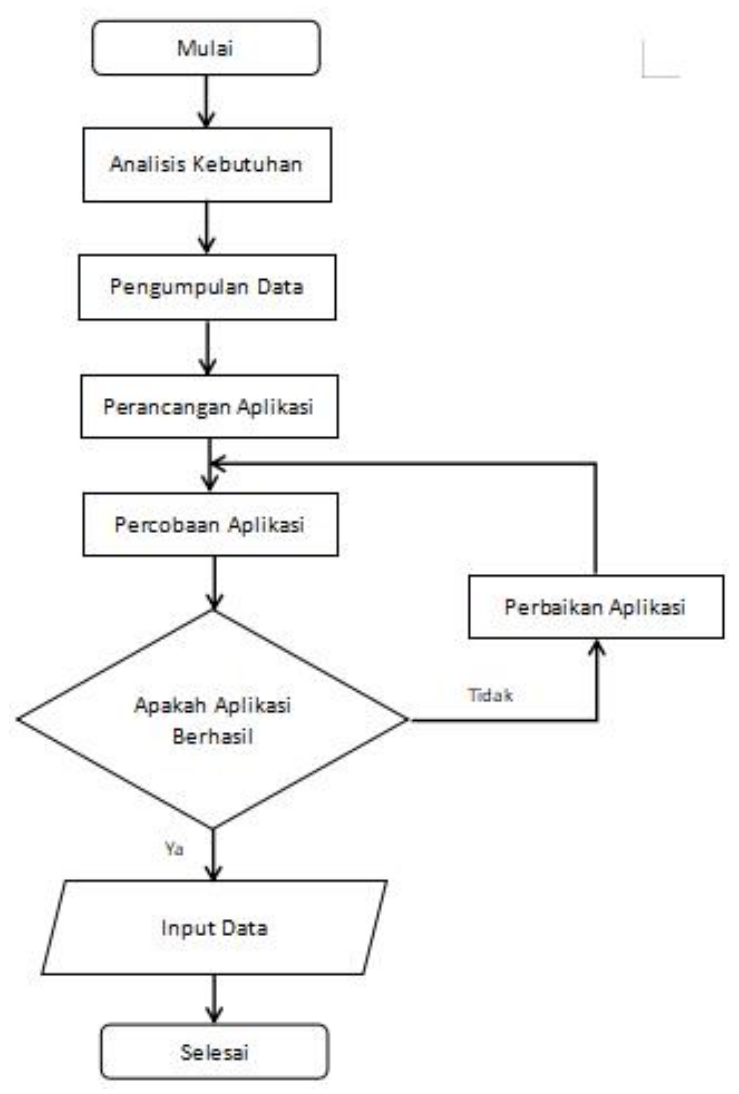

Gambar 1. Flowchart Rancang Bangun e-learning

1. Konfigurasi Awal

Dalam implementasi sebuah e-learning ada beberapa hal yang harus dilakukan agar sistem yang dibuat dapat diakses menggunakan jaringan internet. Untuk membangun sebuah portal e-learning diperlukan sebuah tempat di internet untuk menyimpan data dan sebuah domain (URL) sehingga file atau sistem dapat diakses menggunakan internet dari mana saja.

Dalam penelitian ini penulis menggunakan layanan webhosting dari www.hostinger.co.id. dibawah adalah tampilan awal c-panel.

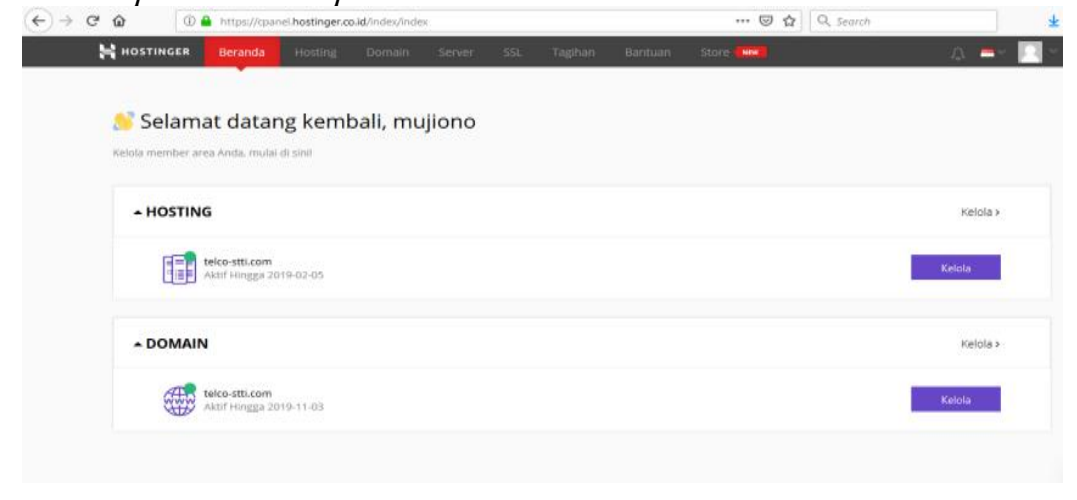

Gambar 2. Tampilan Awal c-panel

Dalam rancang bangun ini penulis menggunakan www.telco-stti.com sebagai nama hosting dan domain. Langkah selanjutnya adalah membuat subdomain. Dalam rancang bangun ini subdomain elearning.telco-stti.com.

\section{Install MOODLE}

Setelah mendapatkan file moodle kita dapat langsung upload ke folder "elearning" pada hosting yang telah kita buat sebelumnya. 


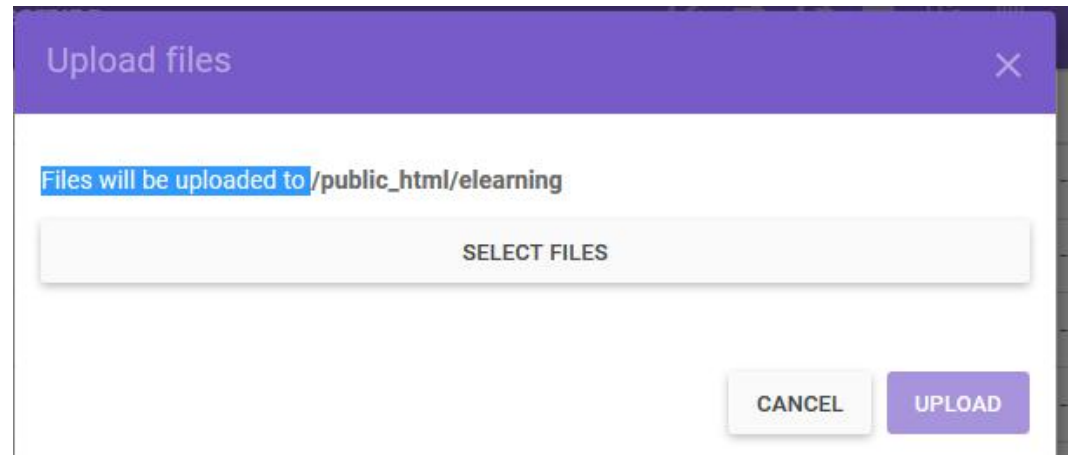

Gambar 3. Upload File Moodle

Setelah file berhasil diupload file langsung dapat langsung di extract

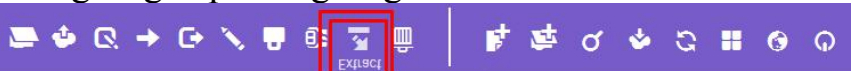

Gambar 5. Extract File

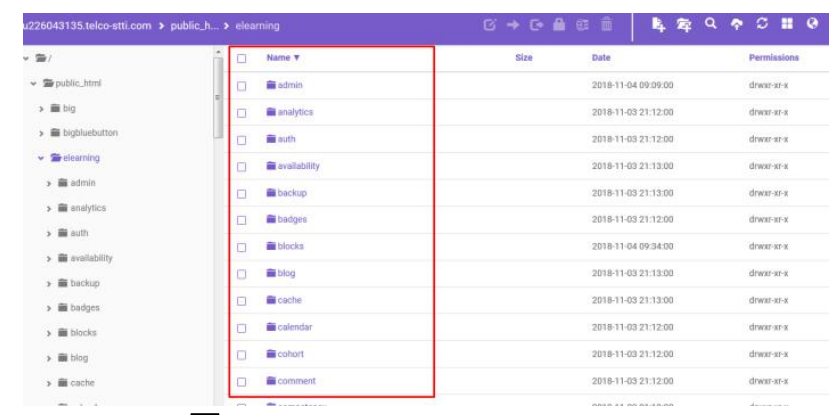

- Gambar 4. File Telah ter-extract

Setelah file berhasil di-extract, buka browser dan buka elearning.telco-stti.com Installation
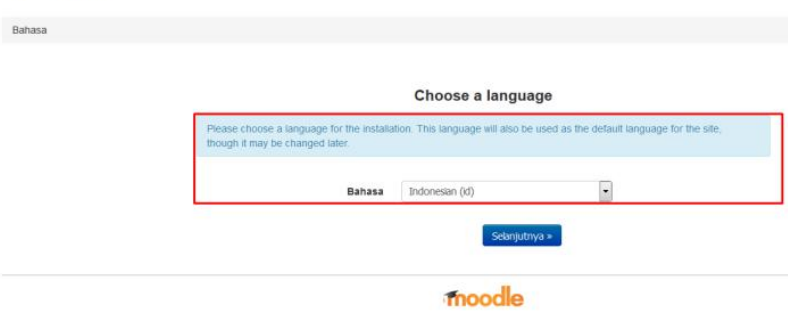

Gambar 5. Halaman elearning.telco-stti.com

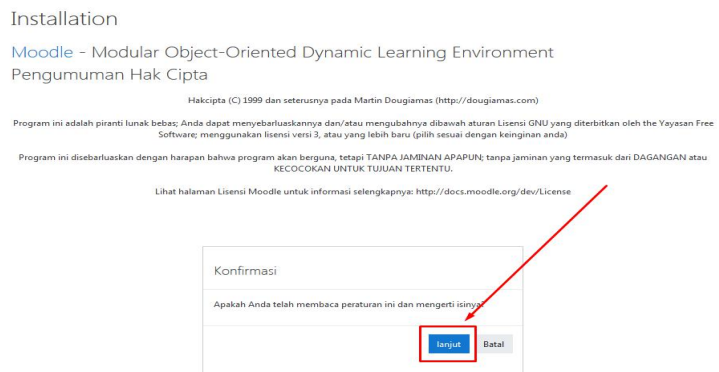

Gambar 6. Halaman Konfirmasi Penggunaan Moodle

Setelah selesai ter-install, terlebih dahulu atur nama pengguna dan kata sandi utama sebagai administrator. 
1. Pengaturan Tema Tampilan

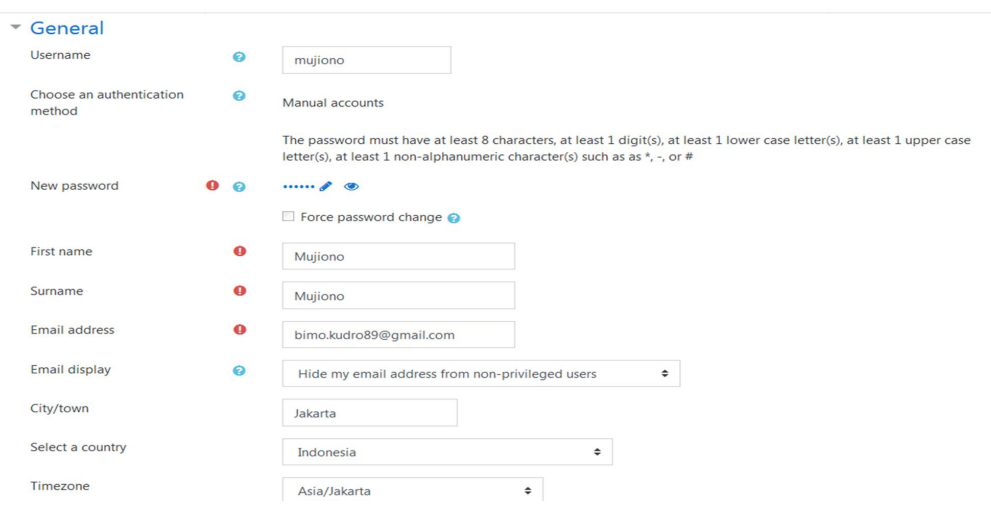

Gambar 7. Pengaturan Akun Administrator

\section{PEMBAHASAN}

Setelah selesai dalam pengaturan administrator langkah berikutnya adalah setting theme hal ini sangat diperlukan karena tampilan tema yng tepat akan membuat halaman e-learning semakin menarik. Di menu setting theme, berisi informasi yang akan menjadi tampilan halaman awal.

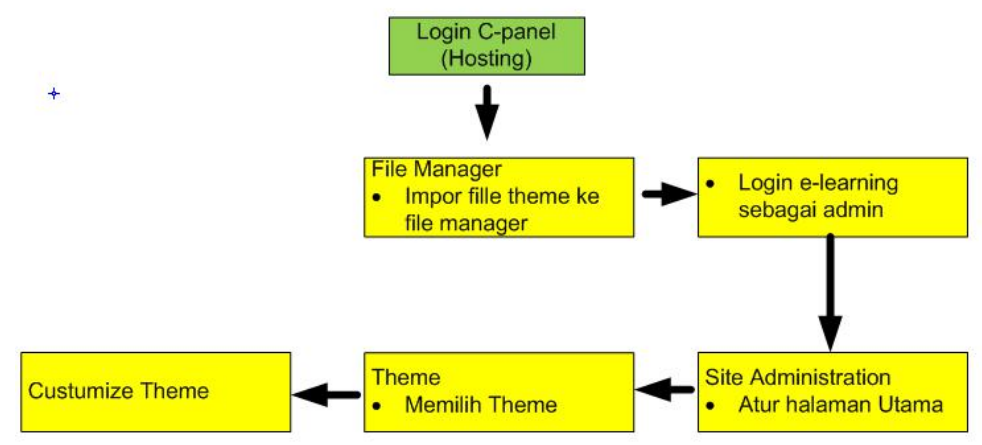

Gambar 8. Pembuatan Tema Baru

Setiap mahasiswa harus memiliki akun untuk bisa masuk dan mengakses konten perkuliahan. Setiap mahasiswa akan dibuatkan akun oleh administrator. Langkah membuat user baru :

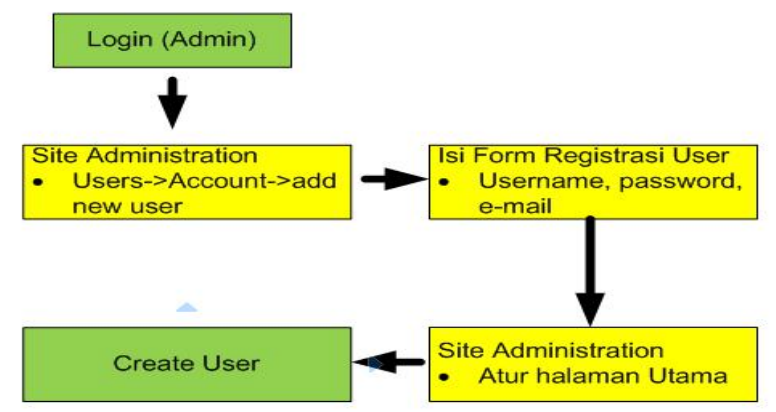

Gambar 9. Pembuatan Akun Pengguna

2. Analisa Menentukan Kategori Mata Kuliah

Di Sekolah Tinggi Teknologi Indonesia ada 3 Prodi yakni ;

1. Prodi Teknik Informatika

2. Prodi Teknik Mesin

3. Prodi Teknik Elektro

Namun dalam penelitian ini penulis mengambil sampling Teknik Elektro yang sesuai dengan jurusan dan peminatan penulis. Di dalam Prodi Teknik Elektro terdiri dari 3 Peminatan yaitu :
1. Elektronika
2. Tenaga Listrik
3. Telekomunikasi 
Untuk membuat kategori mata kuliah langkah-langkahnya adalah sebagai berikut ;

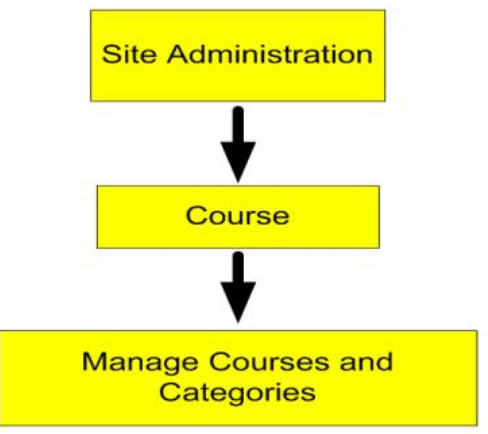

Gambar 10. Pembuatan Mata Kuliah

a) Mendaftarkan akun mahasiswa kedalam mata kuliah

Mata kuliah yang telah dibuat belum bisa diakses oleh mahasiswa sebelum akunnya terdaftar. Untuk mendaftarkan akun mahasiswa dapat mengikuti langkah berikut ;

\section{Dashboard}

2. Courses

3. General

4. Kalkulus I (Pilih mata kuliah dimana peserta akan didaftarkan.)

5. Pada menu Course Administration, pilih Users lalu klik Enrolled Users akan menampilkan gambar sebagai berikut :

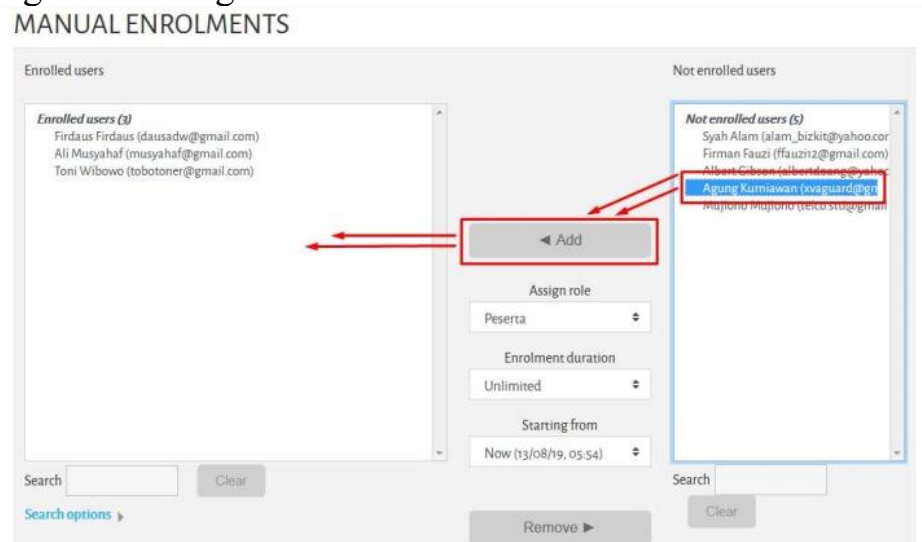

Gambar 11. Memasukkan Peserta Kedalam Mata Kuliah

b) Membagi Mahasiswa ke dalam kelas

Setelah semua akun mahasiswa terdaftar, langkah berikutnya adalah membuat kelas (kelompok belajar) untuk masing masing peminatan.

1. Site administration

2. Users

3. Accounts

4. Cohorts

5. Kemudian pada menu Cohorts klik Add new cohorts

6. Dalam menu Add new cohorts berisikan nama Cohorts ID kelas dan diskripsi. 


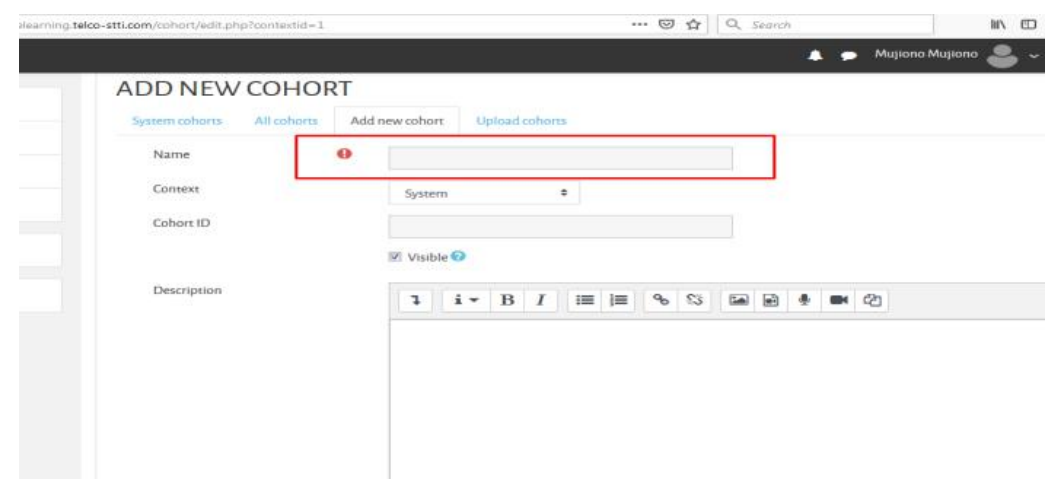

Gambar 12. Menbuat cohort (Kelas)

7. Setelah selesai klik Save change

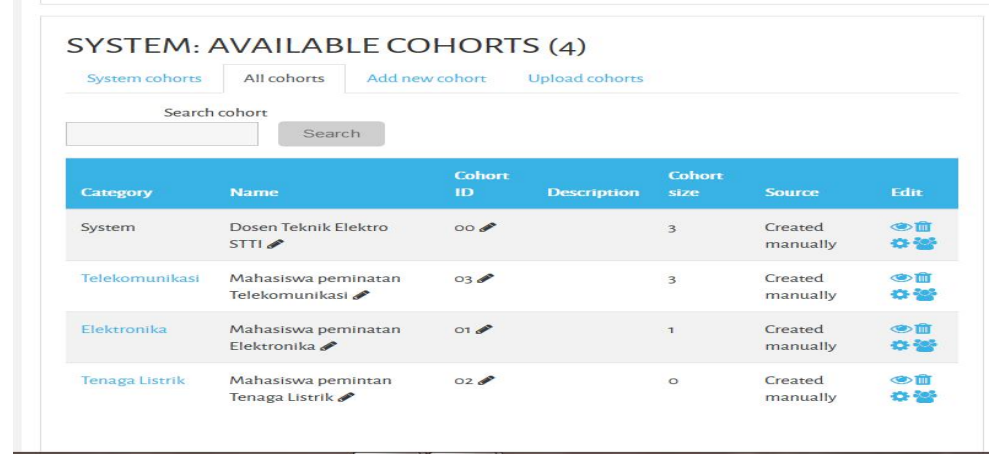

Gambar 13. Daftar cohort

c) Mendaftarkan Dosen dan Mahasiswa dalam sebuah mata kuliah

Setelah mata kuliah dibuat dan User (Dosen dan Mahasiswa) terdaftar langkah berikutnya adalah memasukkannya ke dalam sebuah mata kuliah sesuai dengan ketentuan. Berikut langkah-langkah mendaftrakan dosen dan mahasiswa ke dalam sebuah mata kuliah ;

1. Pilih mata kuliah

2. Klik peserta (participant)

3. klik enroll users

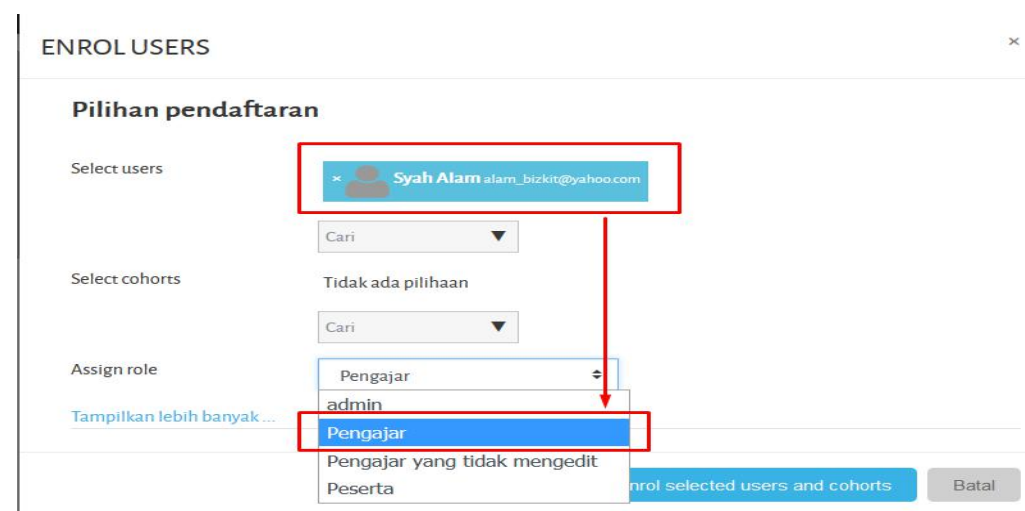

Gambar 14. Mendaftarkan Peserta ke Dalam Mata Kuliah

Dalam Enroll Users yang pertama dilakukan adalah memasukkan akun dosen ke dalam mata kuliah dengan Assign Role sebagai pengajar kemudian klik enroll selected users and cohorts, setelahnya adalah memasukkan mahasiswa dengan memasukkan Cohort yang telah dibuat sebelumnya dengan Assign Role sebagai peserta klik enroll selected users and cohorts untuk memasukkan ke dalam mata kuliah. Setelah semua terdaftar akan ada keterangan seperti gambar di bawah ini pada laman mata kuliah 


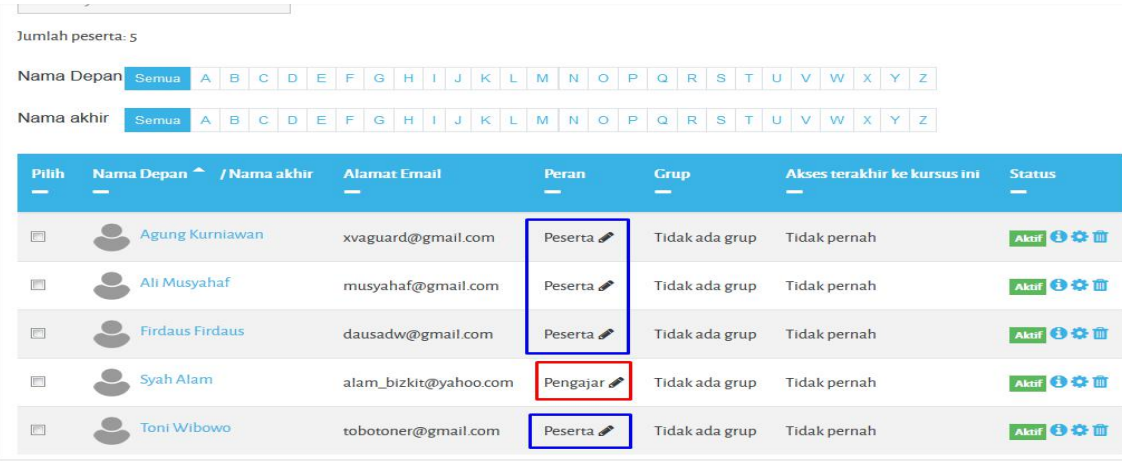

Gambar 15. Daftar Peserta

d) Menyediakan konten e-learning Sekolah Tinggi Teknologi Indonesaia

Penyediaan konten e-learning Sekolah Tinggi Teknologi Indonesia dilakukan oleh admin. Admin menyediakan wadah yang nantinya akan diisi konten perkuliahan oleh dosen terkait mata kuliah bersangkutan. Konten dapat berupa pendahuluan, modul-modul Materi bahan ajar, forum diskusi, tugas mandiri, tes formatif dan dll.

e) Membuat halaman Pendahuluan

Pada kelas konvensional dosen memberikan pendahuluan atau pengantar tentang materi yang akan dipelajari begitu pula dalam e-learning. Langkah-langkah untuk membuat halaman pendahuluan adalah sebagai berikut :

a. Pilih salah satu Topic pada satu mata kuliah. Klik tombol Turn Editing On (menu ini harus selalu aktif setiap melakukan perubahan)

b. Pada bagian pendahuluan/Announcements, klik Add an activity or Resource, pilih Page

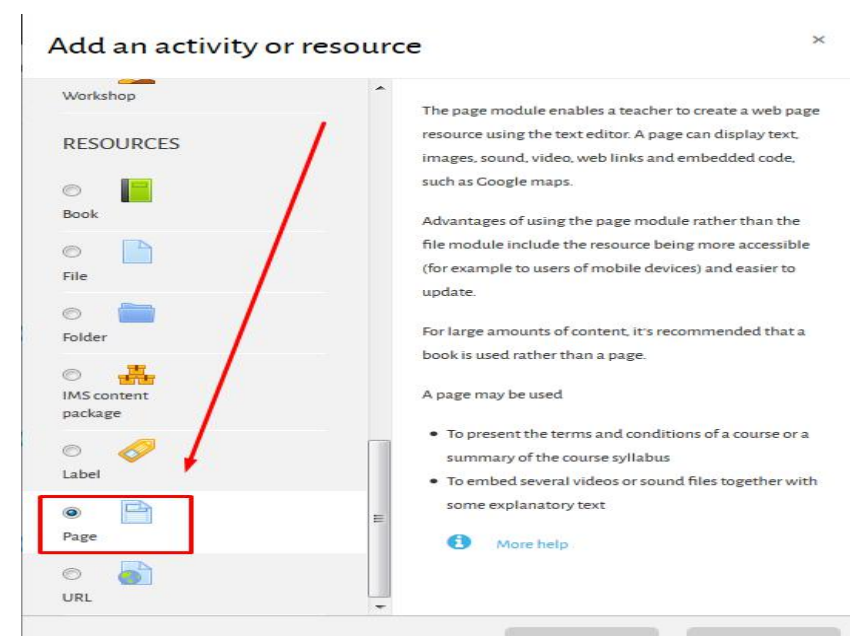

Gambar 16. Memilih Resource Untuk Pendahuluan

c. Setelah masuk ke halaman editing,:

1. Pada bagian general, isi judul dan deskripsi pendahuluan.

2. Pada bagian Content, mengisi halaman pendahuluan kemudian pilih Page Content

3. Klik Save and return to display

f) Pengujian Web E-learning

Pengujian web merupakan rangkaian tahapan yang dilakukan untuk mengetahui kelayakan sitem e-learning ini berjalan sesuai konfigurasi apa tidak. Pada halaman antar muka terdapat menu / bilah untuk login. Dalam hal ini ada beberapa user roles yang dapat mengakses e-learning, yaitu ; Administrator (pembuat web yang dapat mengontrol semua aktifitas), Teacher (bergantung dari administrator diberikan akses untuk merubah course apa tidak), Student (Pelajar/Mahasiswa yang hanya dapat masuk di-course atau assesment yang diberikan oleh adminsitrator atau teacher). 
Tabel 1. Pengujian akses user.

\begin{tabular}{|c|c|c|c|}
\hline User & Pengujian & Bisa & Tidak \\
\hline \multirow{4}{*}{ Administrator } & Login & V & \\
\hline & Apakah bisa melakukan Editing tampilan Web ? & V & \\
\hline & Eroll new user? & $\mathrm{V}$ & \\
\hline & eroll new course? & V & \\
\hline \multirow{6}{*}{ Teacher } & Login & $\mathrm{V}$ & \\
\hline & Dapatkah memasukan matakuliah baru ? & V & \\
\hline & Dapatkah membuat assesment ? & V & \\
\hline & Dapatkah mengunggah file matakuliah ? & V & \\
\hline & Dapatkah enroll student ke dalam matakuliah tertentu ? & $\mathrm{V}$ & \\
\hline & Dapatkah membuat quis berikut dengan penilaian & $\mathrm{V}$ & \\
\hline \multirow{5}{*}{ Student } & Login & $\mathrm{V}$ & \\
\hline & $\begin{array}{l}\text { Dapatkah masuk dan memilih matakuliah yang telah } \\
\text { ditetapkan dosen? }\end{array}$ & $\mathrm{V}$ & \\
\hline & Dapatkah download file materi perkuliahan ? & V & \\
\hline & Dapatkah mengerjakan soal-soal assesment? & $\mathrm{V}$ & \\
\hline & Dapatkah mengerjakan soal-soal quis? & V & \\
\hline
\end{tabular}

Dari hasil pengujian semua user dapat melakukan semua aktifitas yang telah dikonfigurasi oleh administrator. Untuk web bisa diakses melalui laptop/PC maupun smartphone selama terhubung kejaringan internet.

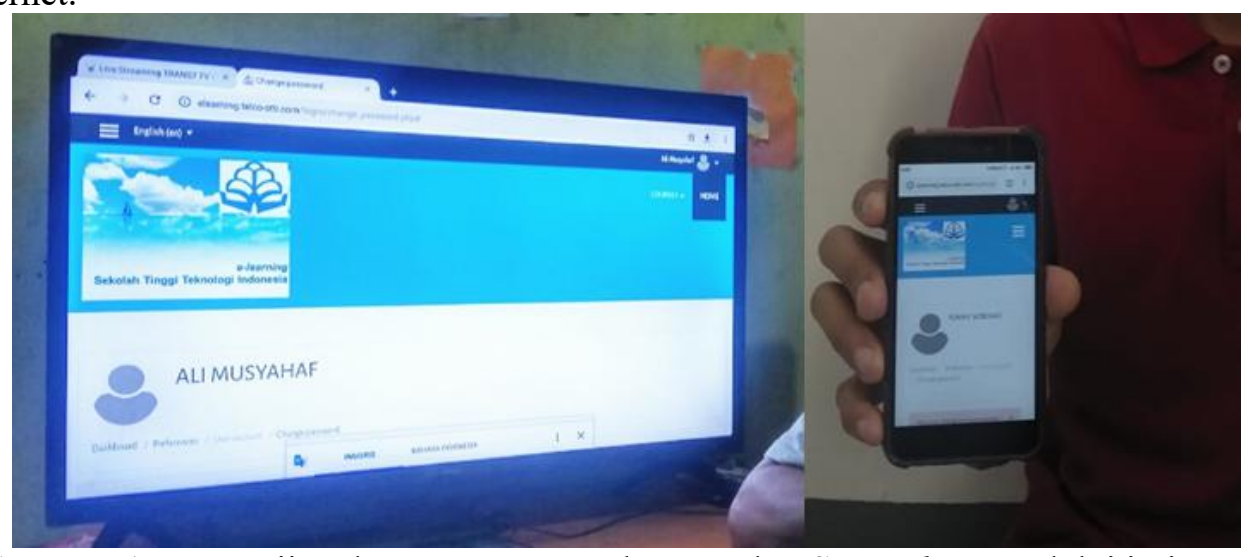

Gambar 17. Pengujian dengan menggunakan PC dan Smartphone melalui jaringan internet

\section{KESIMPULAN}

1. Sistem e-learning yang telah dirancang menggunakan MOODLE sebagai LMS dapat menunjang dan membantu proses belajar dan mengajar jarak jauh.

2. Sistem e-learning Sekolah Tinggi Teknologi Indonesia dapat diakses dengan menggunakan berbagai device, smartphone maupun PC yang terhubung ke jaringan internet. 
3. Dari hasil pengujian dapat diketahui bahwa fungsi-fungsi yang disediakan oleh sistem $e$ learning Sekolah Tinggi Teknologi Indonesia berjalan dengan benar meliputi dapat diakses dengan mudah, materi dapat diunggah maupun diunduh dan sesuai dengan yang diharapkan.

DAFTAR PUSTAKA

[1] Batubara, Hamdan Husein M.Pd.I. "Pembelajaran Berbasis Web Dengan Moodle versi 3.4", 2018

[2] developer.mozilla.org,

"Bagaimana Web Bekerja" (https://developer.mozilla.org/id/docs/Learn/Getting started with the web/How the Web wor ks), 2019

[3] Hostinger.co.id. "Install Moodle Dengan Subdomain di Hostinger", (https://www.hostinger.co.id/artikel-pengetahuan-dasar/bagaimana-cara-menginstall-moodle-disubdomain), 2017

[4] kopertis3.or.id, "Kebijakan Pendidikan Jarak Jauh dan E-Learning di Indonesia", (http://kopertis3.or.id/v2/wp-content/uploads/Paulina-Pannen-Kebijakan-PJJ-dan-ELearning.pdf), 2016

[5] Micro, Andi, "E-learning dengan moodle", 2011

[6] Oktaria, Sheren Dwi Spd, Budiningsih Asri, Risdianto, Eko M.Cs. "Model Blended Learning Berbasis Moodle", 2018

[7] Pamungkas Canggih Ajika, "Rancang Bangun E-learning Center Berbasis WEB Untuk Meningkatkan Kualitas dan Kuantitas Media Pembelajaran Yang Efektif'.Jurnal INFORMA Politeknik Indonusa Surakarta ISSN, 2015

[8] Republika.co.id Layanan E-learning Perguruan tinggi. (https://republika.co.id/berita/nqjkw69/layanan-elearning-perguruan-tinggi), 2015

[9] Syamsul Rizal, Birrul Walidain, "Pembuatan Media Pembelajaran E-Learning Berbasis MOODLE Pada Mata Kuliah Pengantar aplikasi Komputer Universitas Serambi Mekkah". Jurnal Ilmiah DIDAKTIKA, 2019 